\title{
Research on the Sharing Mechanism in the Public Innovation Environment
}

\author{
Honglan Jie \\ Department of Students’ Affairs, Fujian Jiangxia University, Fuzhou, Fujian, 350108
}

Keywords: Public Innovation and Entrepreneurship, Sharing, Environment.

\begin{abstract}
In 2014 China puts forward the "public entrepreneurship, innovation" concept and as a "second Five Year Plan" in the key construction projects. This concept put forward, caused by the country at all levels of concern, is China, the economy, culture, technology, an innovation. The sharing mechanism in this environment gave birth to the "shared economy" rise, for the public industry to provide a new way of thinking. At the same time, the emergence of "shared economy" has also effectively promoted the transformation of China's current economic development model, and injected new vitality into China's social and economic market.
\end{abstract}

\section{Introduction}

Public entrepreneurship, innovation is my country in recent years put forward a new concept of social and economic construction. Its effective to promote the overall level of China's market economy to enhance, but also for China's social employment provides a strong support. In China's current social background, China's economic growth slowed, but the employment has increased, the main reason is that China since joining the WTO, strengthened with the world's economic and trade, but also increased China's domestic market Competitive pressure, prompted the rapid growth of China's new domestic market players. And in this new socio-economic concept, the sharing mechanism to play on China's social and economic development has far-reaching impact. Therefore, this article introduces the public innovation in the entrepreneurial environment, the sharing mechanism in our society in the birth of the "shared economy" to elaborate.

\section{The public innovation concept of entrepreneurship}

In the current social background, has gradually formed a transaction-based, market-based commercialization model. And as China's domestic enterprises continue to be competitive pressure, market competition and social and economic activities, the situation gradually changed. And as China put forward the concept of public innovation and entrepreneurship, China's economic market is a challenge is also an opportunity. And technological innovation is to become the main content of market competition. In the current market environment of Chinese enterprises, with the rise of public entrepreneurship, to our existing enterprises to bring greater pressure, coupled with people's way of thinking and consumption patterns change, have prompted the Chinese enterprises in the new market Environment transformation and reform. And the innovation of our enterprises can effectively promote the market and the economic progress of enterprises, so as to further attract more talent to start a business, forming a benign cycle.

From the current social background of our country, around the "people-oriented" to promote social equity and social development, and in the "State Council on vigorously promote the public entrepreneurship a number of policy measures," the proposed, to solve China's more than 900 million the employment of the labor problem, so that Huimin people, possession of wealth in the people. 


\section{The sharing mechanism under the elements of economic development}

In the new environment of the market sharing mechanism is not limited to the sharing of information, more importantly, to achieve economic sharing. And here refers to the economic sharing refers to the sharing mechanism on the basis of individual and groups to achieve the use of "Internet +" and "cooperative production", "cooperative consumption" and other aspects of common development, and jointly create a new market value, common Sharing the value of the realization of links, but also on China's current manufacturing sector thinking mode of change, and promote the overall level of social and economic development in China to enhance. It includes the following development elements [2].

Computing: refers to the current social environment, the use of computers more and more skilled, people in this era of the Internet, providing a lot of data and sharing information. And people can anytime, anywhere through different ways to achieve the sharing of network data. And in the current information age, the emergence of the computer allows users to achieve any location and any way to extract their own information. Not only that, cloud computer technology in the moment can be achieved between the exchange of users.

Community: in the current social community is characterized by modern network tools to achieve communication, so as to create a platform for groups or individuals. And this phenomenon in our country is more obvious. For example, in the current university groups, through micro-blogging, qq, WeChat friends circle and other functions, to share their own lives, working medium information, to achieve the user and the information exchange between users, and these software is to become The platform, it is precisely because of this phenomenon is prominent in these platforms derived from a similar "micro" businessmen. The emergence of network information platform, breaking the traditional entrepreneurial model and consumer model, to achieve the entrepreneurial and consumer online contact, which will be conducive to the pace of reform of China's entrepreneurial model to speed up.

Customization: refers to customization. With the development of diversified social life, people's consumer awareness is constantly changing, therefore, both in R \& D design or in manufacturing, must meet customer needs as the core, and this customization of the development of the Consumers participate in the traditional industry division of labor system [3].

Here 3P refers to: Public, Private and Product.

In the present environment, government agencies want to adapt to the development trend of society must be based on China's new development concepts and the situation to fully understand the existing laws or norms to make the appropriate adjustments; and on the other hand is necessary To take out more shared resources, the only way to promote the current society to share the economy in a good direction.

Private: that is private. That is, in the enterprise, consumers and stakeholders involved in the adoption of modern network technology, the existing economic products in-depth mining, the creation of value, the value of transmission and other sectors, customers can get personalized products, customized Service, and enterprises can also get the corresponding profits.

Product: the so - called products include production equipment, consumer goods and tools, and these are shared in the economy of China, an important share of the main body, but also in the public business, innovation under the product. The product is the entrance, the social group is the business model. How to effectively combine with the business model and to promote the current social talent entrepreneurship is much important.

"Public entrepreneurship" and "innovation" because of their characteristics between each other, between the two have the role of mutual promotion. And the relationship is: the public to achieve entrepreneurship, and further promote the innovation of entrepreneurship and corporate reform. From the characteristics of the elements of shared economy, $3 \mathrm{C}$ is for the innovation to provide innovative ideas, 3P for the public to provide the conditions for entrepreneurship, thus attracting more talent into the exploration of entrepreneurship and innovation. 


\section{The Meaning of the Share Economy}

According to the above mentioned, the shared economy includes "cooperative production", therefore, our enterprises want to get a breakthrough, it must be a "smile curve" as the basis, to achieve economic model change.

The so-called "smile curve" is an industrial chain, will be divided into different sections - R \& D design, manufacturing, marketing services, and these three sections are in different profit positions. In this one, the manufacturing link is in the "smile curve" in the low profit link. Therefore, the manufacturing company's ultimate goal is to help enterprises to get out of this "position" to achieve a higher profit region to proceed. However, from the actual situation in China, the developed countries in the market in China occupy a high ground, and China's domestic enterprises are in a low-margin manufacturing links. Therefore, to achieve our domestic enterprises to the "smile curve" of the high point of the Chinese enterprises is one of the highest goals [4].

And Chinese enterprises want to get out of the "smile curve" of the low-end area, it must be to the development and service in two directions, that is, through high-tech to achieve industrial upgrading and manufacturing peripheral services development. But with people's way of thinking and consumption habits change, want to achieve this goal, there are still many problems.

But with China into the era of network information, these problems can be a very good solution. Under the action of the sharing mechanism, the creation of traditional manufacturing enterprise value and the change of resource allocation mode are realized by means of network platform, which breaks the traditional concept and realizes the participation of enterprises, customers and stakeholders in value creation, value transfer and value realization And so on. "Internet +" era, "+" is not just information, but also can achieve "physical sharing", so as to form a new value creation and sharing model in China. And created a new era of shared economy in China, effectively promoted the promotion of China's entrepreneurial era, and improved the utilization rate of social resources and the growth of social and economic level.

\section{Conclusion}

As China vigorously promote the "public entrepreneurship, innovation" concept, our society has formed a new type of entrepreneurial trend at the same time, also set off a storm of enterprise innovation. In China's current social environment, the employment pressure surge, entrepreneurship has become a lot of people's choice, and in the enterprise, innovation has become the main force of market competition. Therefore, China's public entrepreneurship, innovation and innovation to promote China's economic growth, scientific and technological innovation and social harmony and stability are far-reaching significance.

\section{References}

[1] Sun Xiao, Liu Hang, Jin Yinzhu. Study on Agile Logistics Management Information Sharing Mechanism Based on Defective Product Recall [J]. Lantai World, 2017, (09): 63-65.

[2] Wang Yongming, Qin Cuiping. Study on the Benefit Sharing Mechanism of Fresh Agricultural Products under Fresh Rescue [J]. Science and Technology, 2017, (01): 51-55.

[3] Li Fang, Zhang Hengquan. Study on information sharing mechanism of large-scale water conservancy and hydropower project [J]. Water Conservancy, 2017, (01): 55-60 + 78.

[4] Zhang Ruilin. Experimental teaching center quality resource sharing management mechanism research [J]. Laboratory research and exploration, 2017, (01): 231-233 +237. 